\title{
REFLECTOR DOWEL STRENGTH TEST FORT ST. VRAIN
}

\author{
by \\ D. W. DOLL
}

This report was prepared as an account of work sponsored by the Uruted States Government. Neither Research and Development the United States Energy Research and Development Administration, not any of
their employees, nor any of ther contractors uubcontractors. of their employees, makes any warranty. express or impled, or assumes any legal liability or responsibility for the accuracy, completeness or usefulness of any information, apparatus, product or process dieclosed, or represents that its use would not
infringe privately owned rights.

Prepared under

Contract E(04-3)-633

for the San Francisco Operations Office

U. S. Energy Research and Development Administration 


\section{DISCLAIMER}

This report was prepared as an account of work sponsored by an agency of the United States Government. Neither the United States Government nor any agency Thereof, nor any of their employees, makes any warranty, express or implied, or assumes any legal liability or responsibility for the accuracy, completeness, or usefulness of any information, apparatus, product, or process disclosed, or represents that its use would not infringe privately owned rights. Reference herein to any specific commercial product, process, or service by trade name, trademark, manufacturer, or otherwise does not necessarily constitute or imply its endorsement, recommendation, or favoring by the United States Government or any agency thereof. The views and opinions of authors expressed herein do not necessarily state or reflect those of the United States Government or any agency thereof. 


\section{DISCLAIMER}

Portions of this document may be illegible in electronic image products. Images are produced from the best available original document. 
• - 


\section{CONTENTS}

1. SUMMARY . . . . . . . . . . . . . . . . . . . . . 1

2. Introduction. . . . . . . . . . . . . . . . . . . 2

3. TEST APPARATUS. . . . . . . . . . . . . . . . . . 3

3.1. Dowe1 Test Samples. . . . . . . . . . . . . . . 3

3.2. Test Fixture. . . . . . . . . . . . . . . . . . . 3

4. TEST PROCEDURE. . . . . . . . . . . . . . . . . . . . . 9

5. RESULTS . . . . . . . . . . . . . . . . . . . 10

5.1. Graphite Socket - Sample 1. . . . . . . . . . . . 10

5.2. Metal Socket - Sample 2.............. . 13

5.3. Metal Socket, Cycled Load - Sample 3. . . . . . . . . 13

6. CONCLUSIONS . . . . . . . . . . . . . . . . . . 18

REFERENCES. . . . . . . . . . . . . . . . . . . . . 20

\section{FIGURES}

1. Standard fuel element hole layout and dowel installation detail . 4

2. Detail of large dowel for FSV fuel elements . . . . . . . . . 5

3. Dowel installation. . . . . . . . . . . . . . 6

4. Test apparatus. . . . . . . . . . . . . . 8

5. Sample No. 1 after failure. . . . . . . . . . . . . 12

6. Sample No. 2 after failure. . . . . . . . . . . . . . . 14

7. Top view of dowel showing location of initial cracked web . . . 16

8. Sample No. 3 after complete failure . . . . . . . . . . . . 17

\section{TABLES}

1. Load and deflection at failure. . . . . . . . . . . . . 11

2. Load and deflection at first indication of failure. . . . . . . . 11 


\section{SUMMARY}

The strength of the $44.45 \mathrm{~mm}$ (1.75 in.) diameter Fort St. Vrain (FSV) reflector dowel for loads directed radially inward toward the center of the element was measured. For a statically applied load, the strength exceeded $5783 \mathrm{~N}(1300 \mathrm{lb})$ in direct shear. This strength remained after load cycling 100 times to $4448 \mathrm{~N}(1000 \mathrm{lb}), 10$ times to $4893 \mathrm{~N}(1100 \mathrm{lb}), 10$ times to $5338 \mathrm{~N}(1200 \mathrm{1b})$, and two times to $5783 \mathrm{~N}(1300 \mathrm{1b})$. Typically, the deflection to ultimate failure was $\sim 1.0 \mathrm{~mm}(0.04 \mathrm{in}$.). At about $3316 \mathrm{~N}$ $(750 \mathrm{lb})$ and $0.20 \mathrm{~mm}(0.008 \mathrm{in.})$ deflection, one of the webs between the dowel and a coolant hole cracked, apparently redistributing the load. No further failure occurred up to the ultimate load of $5783+\mathrm{N}(1300+1 \mathrm{~b})$. 


\section{INTRODUCTION}

When the orifice flow valve is in the near fully closed position and the reactor is at maximum power, the pressure drop across the valve and plenum can reach 72,400 pascals (10.5 psi) (Ref. 1). This pressure difference surrounds the entire region and tends to hold the columns within a region together. Because of thermal expansion differences between graphite and metal, the surfaces of the reflector and plenum elements are not in direct contact throughout the full operating cycle from startup through operation to refueling. This allows forces to build up on the dowels as the pressure tends to force the columns inward. The geometry of the threaded connection between the dowel and the reflector element is complex and difficult to model analytically. A strength test was performed to establish the load capacity of this feature.

Tests of dowel strength were performed on the large [44.45 mm (1.75 in.) diameter] dowels in FSV fuel blocks (Ref. 2). The results showed failure loads that ranged from $4252 \mathrm{~N}(956 \mathrm{lb})$ to $5832 \mathrm{~N}(1311 \mathrm{lb})$. In each case failure occurred in the threaded socket. The presence of the fuel holes around the dowel reduces the amount of supporting material for shear loads. For this reason, the results of the fuel element tests are not applicable to a reflector element that does not have the fuel holes. The tests reported herein are aimed at measuring the dowel strength of a reflector element with coolant holes. 


\section{TEST APPARATUS}

The test apparatus consisted of dowels cemented into sections of a fuel block, a fixture for holding the sections, a simulated socket, and a tensile testing machine.

\subsection{DOWEL TEST SAMPLES}

Three dowel test samples were assembled. Each consisted of a $254.0 \mathrm{~mm}$ (10 in.) thick section of a standard fuel block with one $44.45 \mathrm{~mm}$ (1.75 in.) diameter dowel cemented into a threaded socket. The sections were removed from the undamaged end of a rejected production fuel block. Threaded sockets were machined into the exposed surfaces in the same manner and in the same location as the original single dowel (see Fig. 1). Standard production dowels as shown in Fig. 2 were used.

In order to simulate a reflector block using a fuel block, the fuel holes surrounding the dowel were plugged with standard fuel hole plugs stacked one on another and cemented (Fig. 3). After plugging the holes, the dowels were installed. Curing was done in the conventional manner as specified in the fuel specifications.

\subsection{Test Fixture}

The test fixture consisted of a clamping arrangement that held the block section and a frame with a dowel socket attached. Two types of socket were used: one socket was machined from 6061-T6 aluminum and the other from type $\mathrm{H}-451$ graphite. The socket inside diameter was $45.47 \pm$ $0.13 \mathrm{~mm}(1.79 \pm 0.005$ in.). 

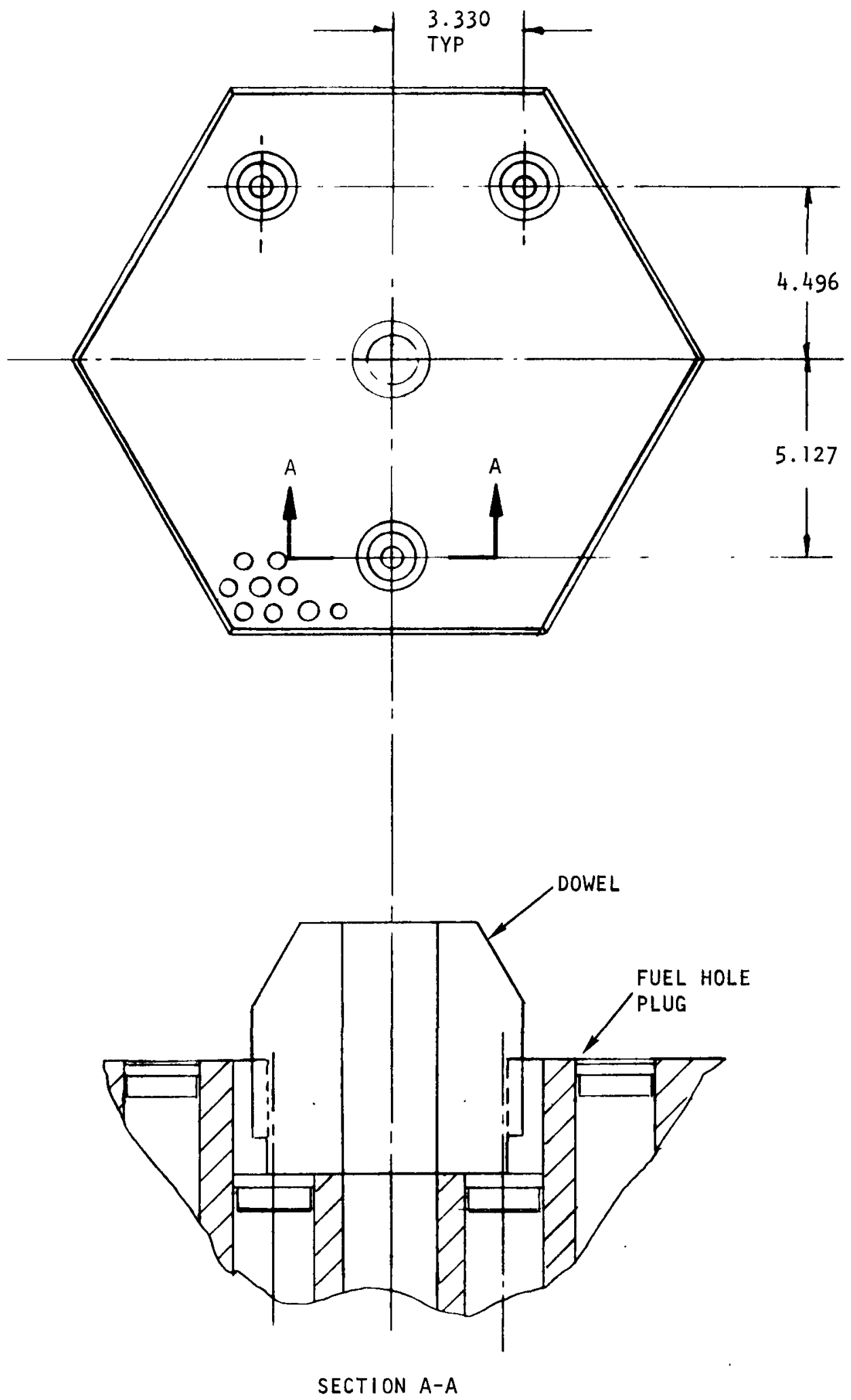

Fig. 1. Standard fuel element hole layout and dowel installation detail 


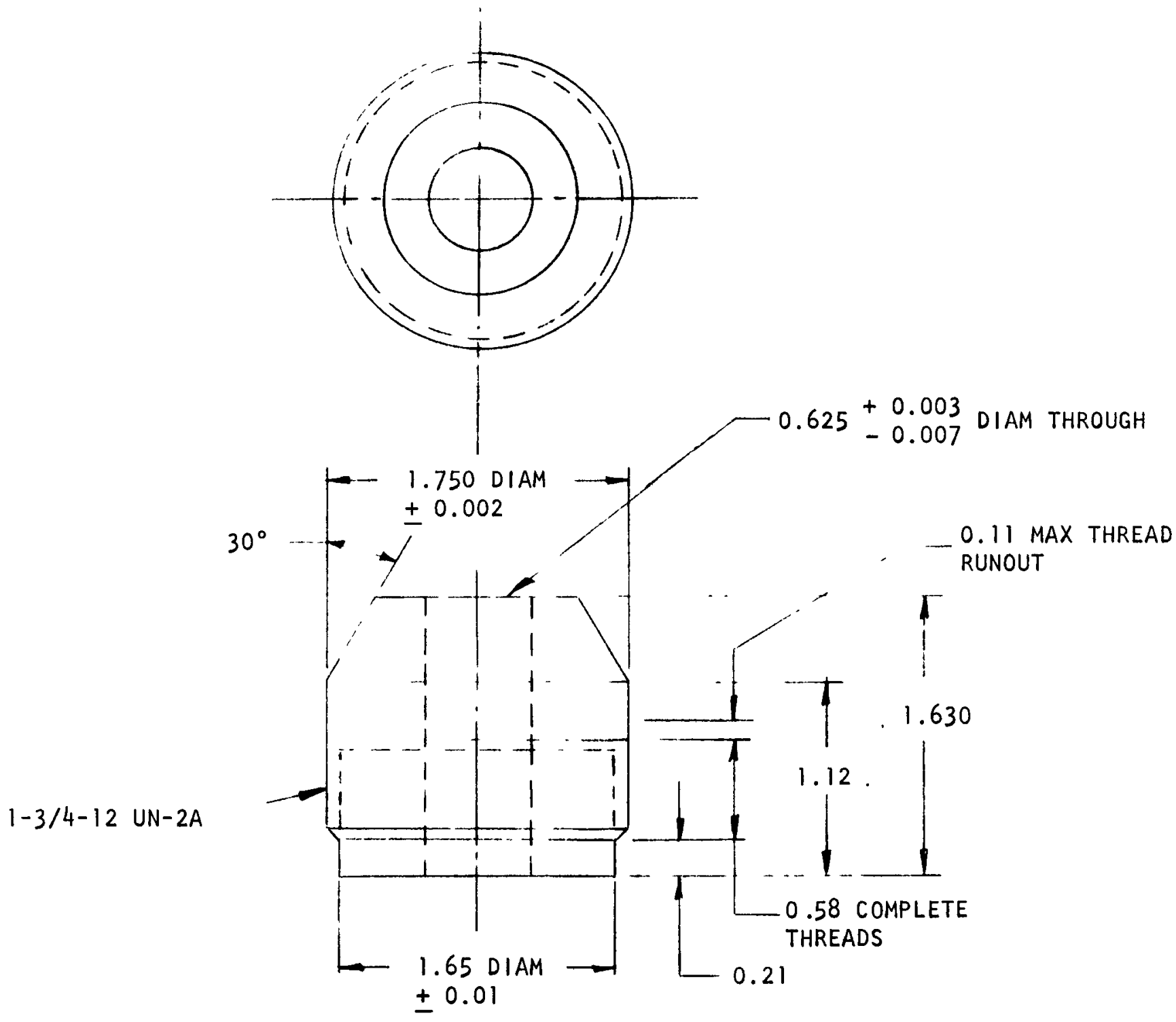

Fig. 2. Detail of large dowel for FSV fuel elements 

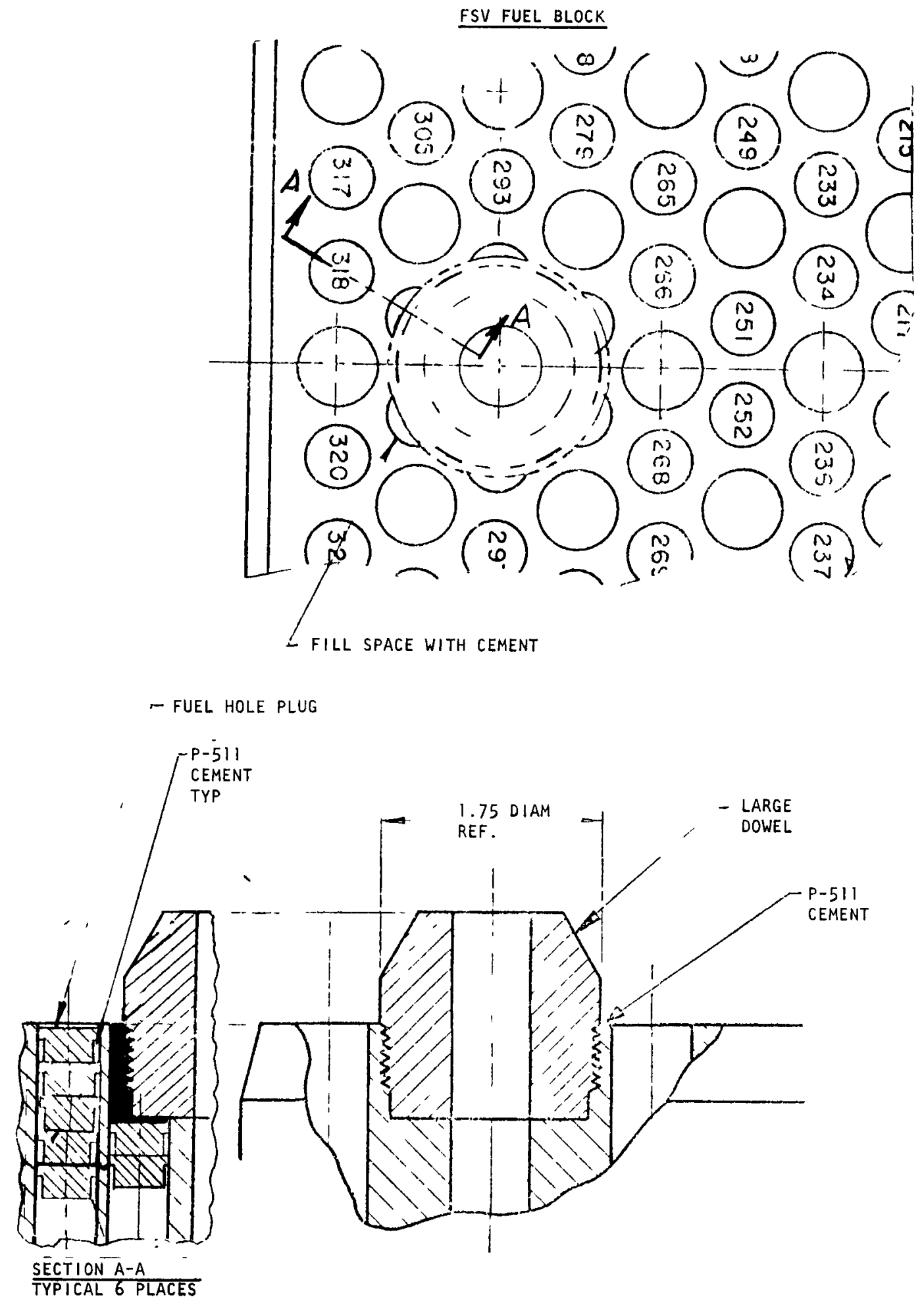

Fig. 3. Dowel installation 
The clamping frame was attached to the base of a Baldwin universal testing machine [type So $640-2632 ; 266,893 \mathrm{~N}(60,000 \mathrm{1b})$ capacity] and the frame holding the dowel was attached to the crosshead. The deflections were measured on a Baldwin extensometer (type $\mathrm{PD}-1-\mathrm{M}$ ) and recorded on a Microformer recorder, which read out load versus deflection directly (without chart speed conversion). The assembly is shown in Fig. 4. 


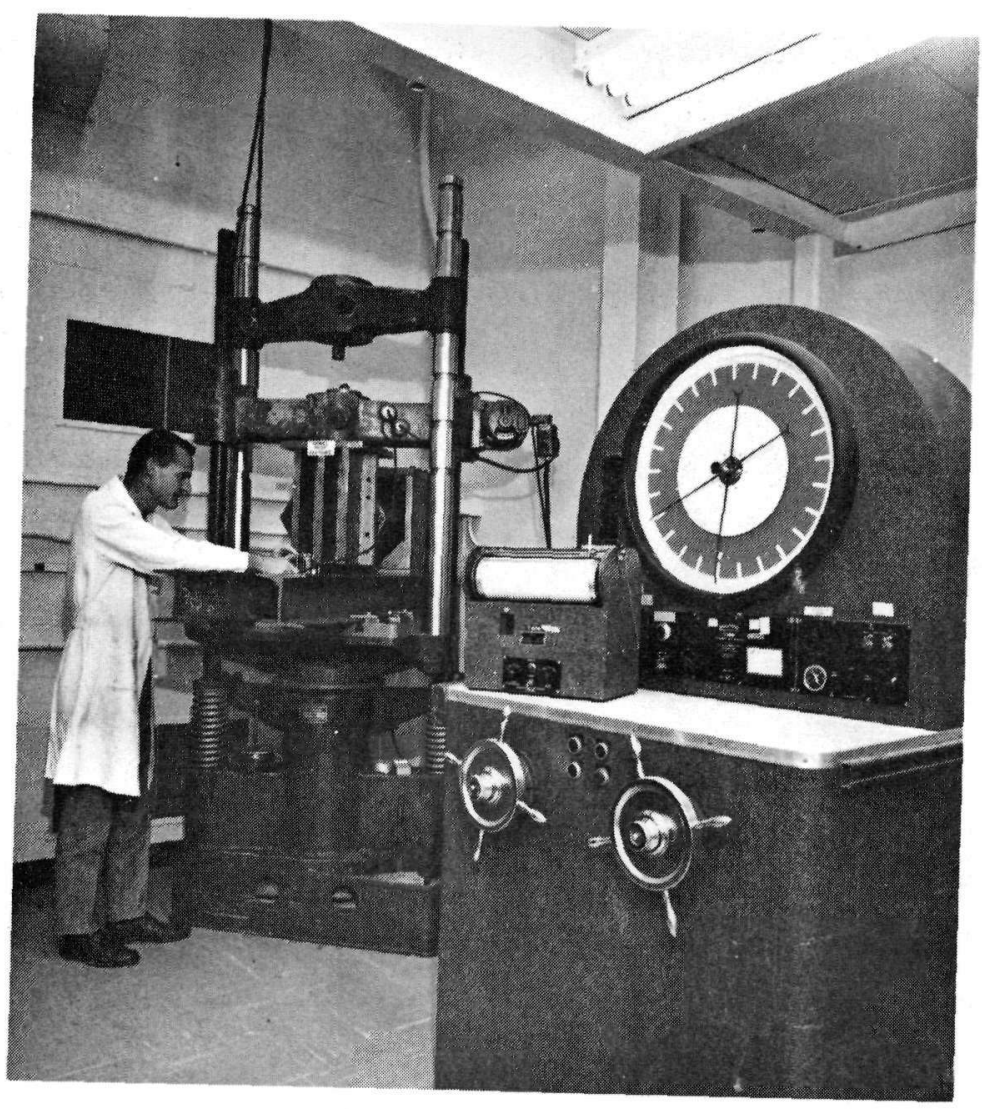

HT98815

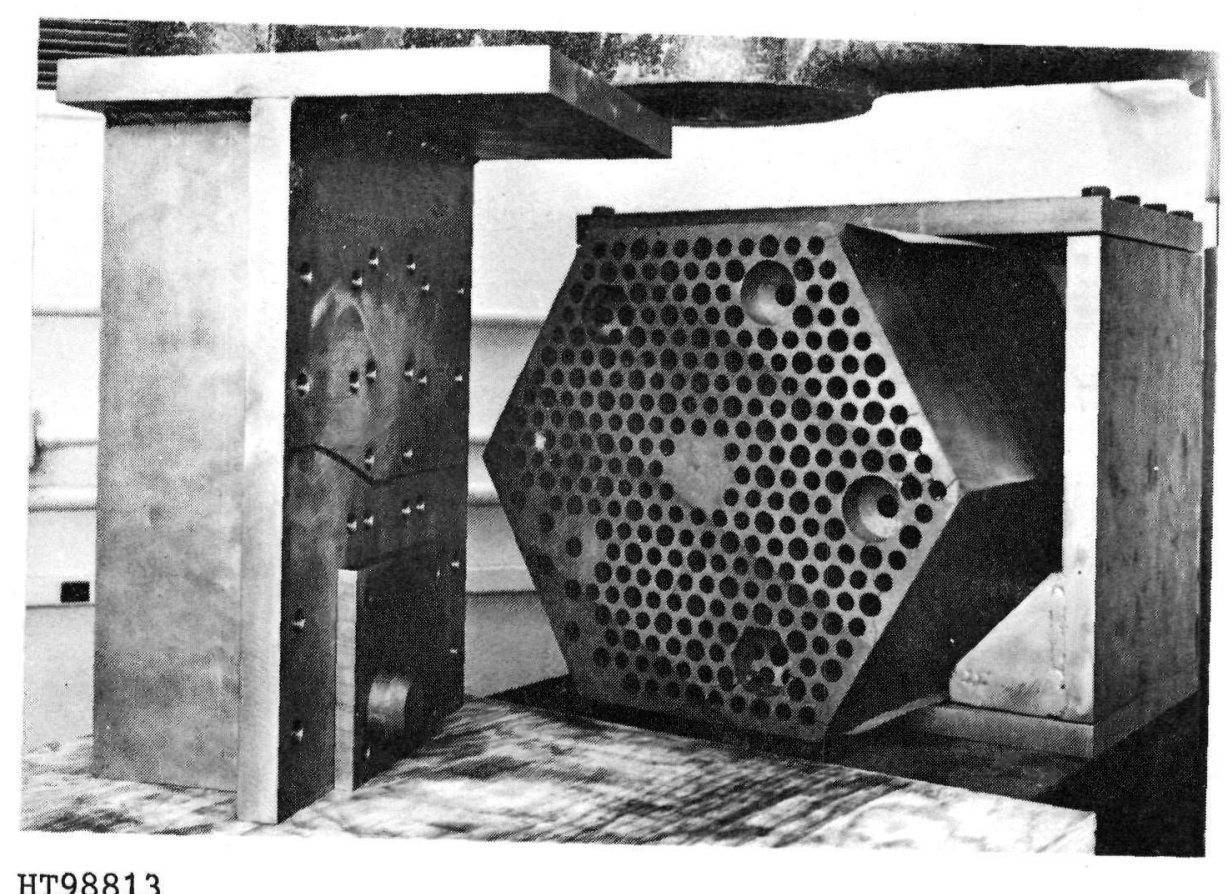

Fig. 4. Test apparatus 


\section{TEST PROCEDURE}

Three assembled dowels were tested to their ultimate strength in direct shear. A crosshead speed of $20.76 \mathrm{~mm}$ (0.003 in.)/min was maintained for all tests (control was hand operated). The first sample was loaded using a graphite socket in order to simulate a reflector-to-reflector connection. The second was loaded using the metal socket to simulate the connection between the plenum and the reflector elements. In both cases the load was applied until evidence of failure was observed.

The third sample was mounted in the same manner as the second sample using the metal socket. The load was applied up to $4448 \mathrm{~N}(1000 \mathrm{Ib})$ and released for 50 cycles. The sample was removed, inspected, reinstalled in the fixture, and loaded 50 more times up to $4448 \mathrm{~N}(1000 \mathrm{lb})$ for a total of 100 cycles. The load was increased by $445 \mathrm{~N}$ (100 1b) increments and cycled to zero 10 times at each load. This was repeated until failure. The sample was then removed and inspected. 


\section{RESULTS}

In this series of tests the ultimate strength of the large $44.45 \mathrm{~mm}$ (1.75 in.) diameter dowels used in upper reflector elements was measured. The loads applied were in direct shear perpendicular to the dowel axis and toward the center of the block. The ultimate loads are summarized in Table 1 and the load at the first indication of failure is summarized in Table 2. The load on one sample was cycled to investigate the possible effects of fatigue.

\subsection{GRAPHITE SOCKET - SAMPLE 1}

The ultimate strength measured for the dowel when loaded in direct shear using a graphite socket was $5960 \mathrm{~N}(1340 \mathrm{lb})$; the total deflection was $1.04 \mathrm{~mm}$ (0.041 in.). At about $3780 \mathrm{~N}(850 \mathrm{lb})$, the deflection constant (load/deflection) changed from $7175 \mathrm{~N} / \mathrm{m}(63,5001 \mathrm{~b} /$ in.) to $4960 \mathrm{~N} / \mathrm{m}$ (43,900 1b/in.). The deflection at this point was $0.41 \mathrm{~mm}(0.016 \mathrm{in.})$. After the abrupt change in slope, the load continued until failure. Some flattening was noted near the ultimate load, but this is attributable to some load redistribution.

The dowe1 assembly was removed and inspected. Figure 5 shows the dowel and surrounding webs of the element. Failure occurred between the dowel and the adjacent coolant holes as the dowel appeared to rotate in the threaded socket holding it. The additional cracking radiating out to the fuel holes was the result of excessive deflection that was permitted after the failure load was reached. 
TABLE 1

LOAD AND DEFLECTION AT FAILURE

\begin{tabular}{c|c|c}
\hline $\begin{array}{c}\text { Sample } \\
\text { No. }\end{array}$ & $\begin{array}{c}\text { U1timate Strength } \\
{[\mathrm{N}(1 \mathrm{~b})]}\end{array}$ & $\begin{array}{c}\text { Total } \\
\text { Deflection } \\
{[\mathrm{mm} \text { (in.) }]}\end{array}$ \\
\hline 1 & $5960(1340)$ & $1.04(0.041)$ \\
2 & $6120(1375)$ & $0.97(0.038)$ \\
3 & $5780(1300)$ & Not determined \\
\hline
\end{tabular}

TABLE 2

LOAD AND DEFLECTION AT FIRST INDICATION OF FAILURE

\begin{tabular}{c|c|c}
\hline $\begin{array}{c}\text { Sample } \\
\text { No. }\end{array}$ & $\begin{array}{c}\text { Load at First } \\
\text { Failure } \\
{[N(1 b)]}\end{array}$ & $\begin{array}{c}\text { Deflection } \\
{[\mathrm{mm} \text { (in.) }]}\end{array}$ \\
\hline 1 & $3780(850)$ & $0.41(0.016)$ \\
2 & $3670(825)$ & $0.28(0.011)$ \\
3 & $3220(725)$ & $0.28(0.011)$ \\
\hline
\end{tabular}




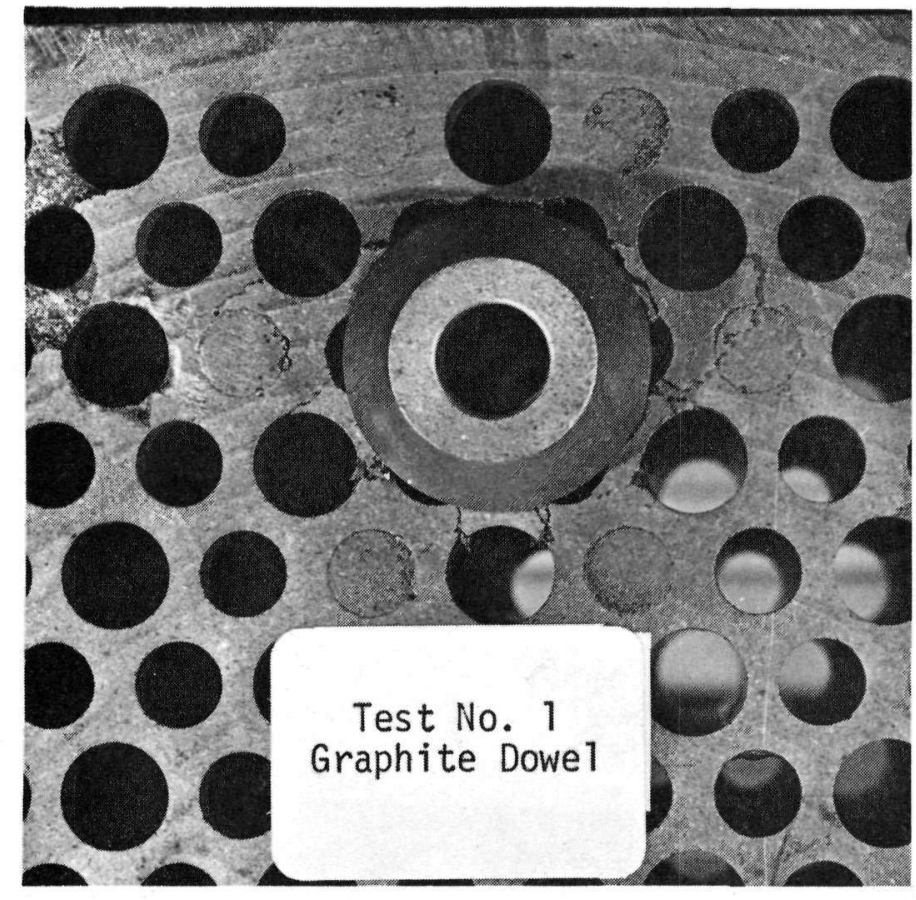

$75 \mathrm{HT} 1216$

Fig. 5. Sample No. 1 after failure 


\subsection{Meta1 Socket - Sample 2}

The ultimate strength measured for a dowel and a metal socket was $6120 \mathrm{~N}$ (1375 1b) (in shear as for sample 1); the total deflection was $0.965 \mathrm{~mm}$ (0.038 in.). As in the test of sample 1, a change in the deflection constant was observed. This occurred at about $3670 \mathrm{~N}$ (825 1b) and $0.28 \mathrm{~mm}$ (0.011 in.) deflection and changed from about $15.9 \mathrm{MN} / \mathrm{m}(90,600$ lb/in.) to about $5.08 \mathrm{MN} / \mathrm{m}(29,000 \mathrm{lb} / \mathrm{in}$.$) . In terms of a system of a$ dowel and socket, the actual constant would be about half this amount.*

In order to establish averages of the deflection constants, several samples would have been required. Obtaining these data was not the purpose of this test. Therefore, the repeated tests were not conducted.

Loading was continued until failure was evident and then released. The failure mode was similar to that for sample 1, i.e., cracks propagating outward from the dowel socket to surrounding coolant holes (see Fig. 6). The dowel remained relatively undamaged and appeared to rotate in the threaded socket.

\subsection{Metal Socket, Cycled Load - Sample 3}

A dowel made the same as samples 1 and 2 was first loaded up to $4450 \mathrm{~N}$ (1000 1b) and released 100 times. As in the tests with the first two samples, during the first cycle an abrupt change in the load was observed. At $\sim 3220 \mathrm{~N}$ (725 1b) load and $0.18 \mathrm{~mm}$ (0.007 in.) deflection, the load dropped to $2890 \mathrm{~N}(650 \mathrm{1b})$ and then continued to $4450 \mathrm{~N}(1000 \mathrm{lb})$ at a different deflection constant. The constant started at $12.7 \mathrm{MN} / \mathrm{m}$ (72,500 1b/in.)

$*$

The dowel and socket can be compared to two compression springs working in series. The equivalent spring in this case is described as: $\mathrm{K}_{\mathrm{e}}=\mathrm{K}_{1} \mathrm{~K}_{2} /\left(\mathrm{K}_{1}+\mathrm{K}_{2}\right)$, where $\mathrm{K}_{1}$ and $\mathrm{K}_{2}$ are spring constants for the dowel and socket, respectively. A graphite dowel in a graphite socket would make $\mathrm{K}_{1} \simeq \mathrm{K}_{2}$ and, therefore, $\mathrm{K}_{\mathrm{e}}=\mathrm{K}_{1,2} / 2$. For a graphite dowe1 in a meta1 socket $\mathrm{K}_{\mathrm{e}} \gg \mathrm{K}_{1}$, which gives $\mathrm{K}_{\mathrm{e}} \simeq \mathrm{K}_{1}$, the dowel constant. 


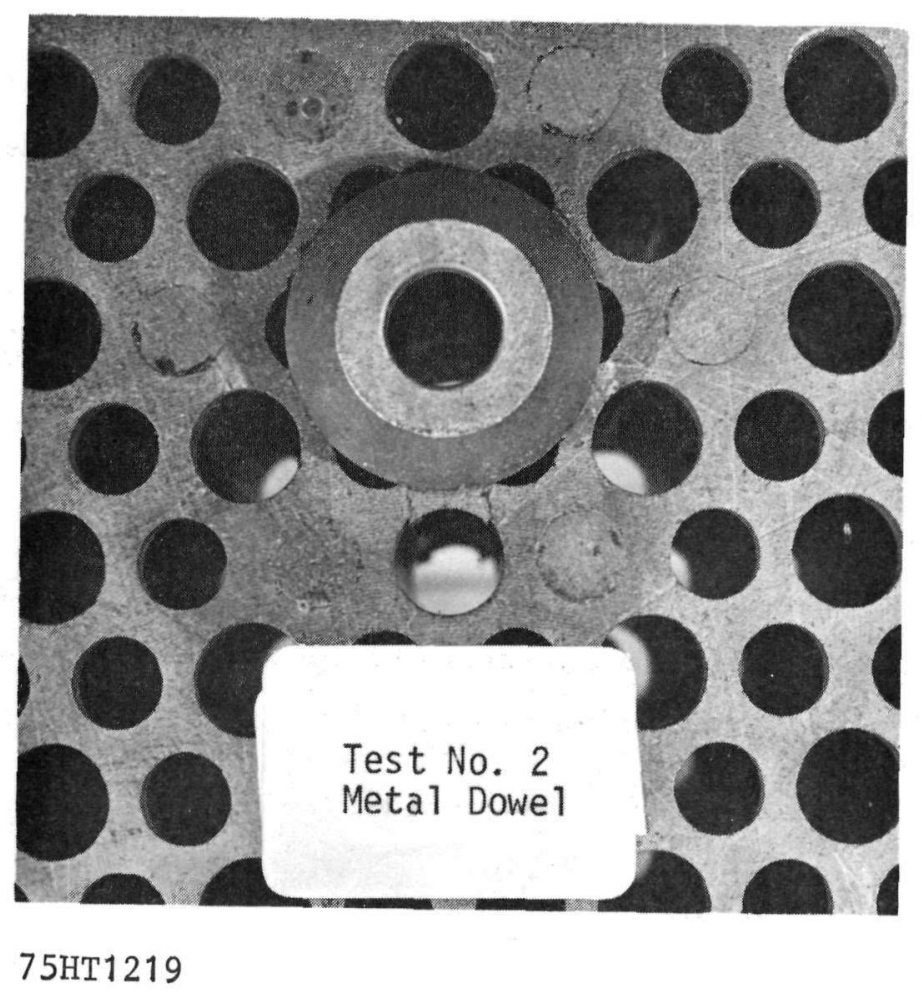

Fig. 6. Sample No. 2 after failure 
and changed to $8.06 \mathrm{MN} / \mathrm{m}(46,000 \mathrm{lb} / \mathrm{in}$.$) . On the second and subsequent$ cycles, the constant remained approximately $11.6 \mathrm{MN} / \mathrm{m}(66,000 \mathrm{lb} / \mathrm{in}$.$) .$

After 50 cycles the sample was removed and inspected. The web on one side of the dowel was cracked (see Fig. 7). No overall displacement was evident, nor were any other webs cracked.

The sample was returned to the test fixture and loaded to $4450 \mathrm{~N}$ (1000 1b) for 50 more cycles. No abrupt changes in the load-deflection curves were noted. The deflection constant gradually decreased from $11.6 \mathrm{MN} / \mathrm{m}(66,000 \mathrm{lb} / \mathrm{in.})$ to $9.6 \mathrm{MN} / \mathrm{m}(55,000 \mathrm{lb} / \mathrm{in.})$ over the 99 cycles following the initial change. Some nonlinearity appeared to develop, which probably was due to deflection of the frame.

After the 100 cycles at $4450 \mathrm{~N}(1000 \mathrm{lb})$, the load was increased to $4890 \mathrm{~N}(1100 \mathrm{lb})$ and cycled 10 times. The deflection constant was $8.9 \mathrm{MN} / \mathrm{m}$ (51,000 1b/in.), which is nearly the same as at the end of the 100 cycles. No abrupt changes were observed in the load traces.

The load was increased to $5340 \mathrm{~N}(1200 \mathrm{1b})$ and cycled 10 more times. For the first cycle, the deflection constant was $28.6 \mathrm{MN} / \mathrm{m}(49,000 \mathrm{lb} / \mathrm{in}$.). By the tenth cycle, the constant had decreased to $7.1 \mathrm{MN} / \mathrm{m}(44,000 \mathrm{1b} / \mathrm{in}$.$) .$

At $5780 \mathrm{~N}$ (1300 1b) load, one full cycle was made. Failure occurred on the second cycle. The deflection constant on this cycle was $7.0 \mathrm{MN} / \mathrm{m}$ (40,000 1b/in.), which showed a further reduction from the tenth cycle at $5340 \mathrm{~N}(1200 \mathrm{lb})$. The sample was removed and inspected. Failure was similar to that of samples 1 and 2 , as can be seen from Fig. 8. 


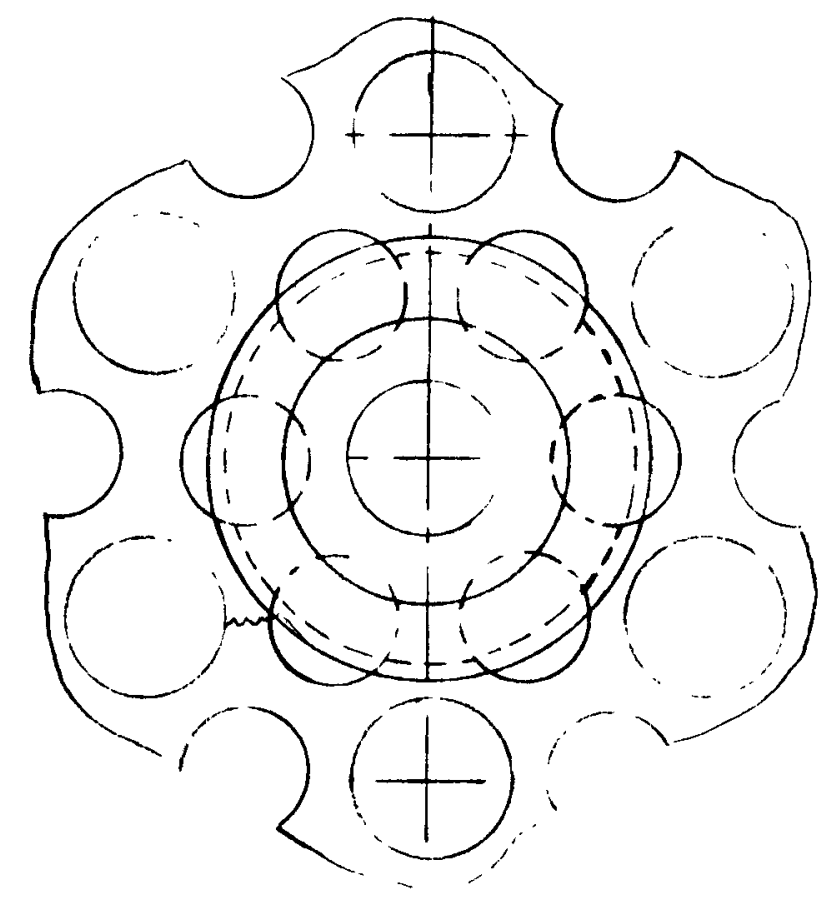

Fig. 7. Top view of dowel showing location of initial cracked web 


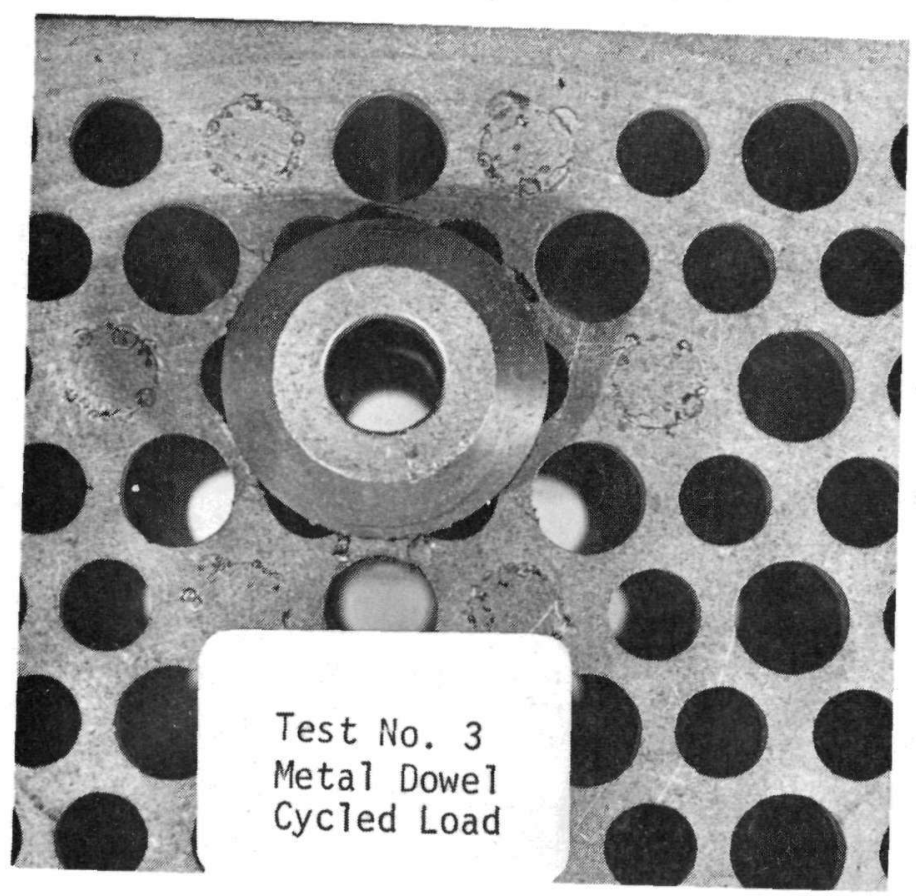

75HT1217

Fig. 8. Sample No. 3 after complete failure 


\section{CONCLUSIONS}

Although the test was limited to three samples and some allowances had to be made for the block having fuel holes, several conclusions can be drawn from the data:

1. The ultimate shear strength of a dowel in a reflector block is greater than $5780 \mathrm{~N}(1300 \mathrm{lb})$. This is somewhat higher than the strength of a dowel in a fuel block, perhaps by $900 \mathrm{~N}$ (200 1b) (Ref. 2). The additional support in the fuel holes, which was simulated with plugs, is probably the reason.

2. The material used for the socket (metal or graphite) affects the deflection constant somewhat but not the ultimate strength. This implies that the strength of the connection between a plenum and the top reflector is not significantly different than that between reflector elements.

3. The ultimate strength is not greatly diminished by load cycling. Up to $4450 \mathrm{~N}(1000 \mathrm{1b})$ or $75 \%$ of the ultimate, there appears to be little change in the load-deflection behavior. Above this amount, however, the dowel seems to become softer (lower deflection rate).

4. At a shear load of between $3110 \mathrm{~N}(700 \mathrm{1b})$ and $3780 \mathrm{~N}$ $(850 \mathrm{lb})$, one of the webs cracks and the deflection rate changes. This occurs at about $0.18 \mathrm{~mm}$ (0.007 in.) to 
$0.25 \mathrm{~mm}(0.01 \mathrm{in.})$ deflection. The abrupt change in the load-deflection behavior has been observed in all previous dowel shear tests (Ref. 3).

The cracked web does not seem to pose a serious problem. It does not expose fuel or block coolant flow. However, if the load is to be limited to that at which the first crack develops, the capacity of the dowel/socket will have to be revised downward by nearly $40 \%$. 


\section{REFERENCES}

1. Final Safety Analysis Report, Fort St. Vrain Nuclear Generating Station, Section 4.4 .

2. "Public Service Company of Colorado 330-MW(e) High-Temperature GasCooled Reactor Research and Development Program Quarterly Report for Period Ending June 30, 1966," USAEC Report GA-7314, General Atomic, Division of General Dynamics, September 30, 1966, Table 3.1., page 29.

3. Stenger, D. C., "2000/3000 MW(t) Hexagonal Element Dowel/Socket Strength Test Report," General Atomic Company unpublished data. 